Весна Крајишник

Универзитет у Београду

Филолошки факултет
UDC 371.3:811.163.41'246

DOI https://doi.org/10.18485/fid.2018.8.ch5

\title{
СТАЊЕ У НАСТАВИ СРПСКОГ КАО НЕМАТЕРЊЕГ ЈЕЗИКА И ПРЕПОРУКЕ ЗА ЊЕН РАЗВОЈ У ХОМОГЕНИМ ЈЕЗИЧКИМ СРЕДИНАМА
}

\section{Сажетак}

Настава српског као нематерњег језика има дугу традицију у нашој вишенационалној и вишејезичкој средини. Ученици чији матерњи језик није српски имају право да се образују (на нивоу основне и средње школе) на свом матерњем језику, уз обавезно учење српског језика са циљем да им се омогући укључивање у ширу друштвену заједницу. Међутим, последњих година, као последица много ширих политичких и друштвених промјена, примијећени су изузетно лоши резултати у познавању српског језика код припадника националних мањина чији матерњи језик није сродан српском и који живе у језички хомогеним срединама (Албанци и Мађари). У покушају да се проблем сагледа са што више страна и да се што прецизније идентификују узроци и могућа рјешења, покренут је пројекат од стране Службе Координационог тела Владе Републике Србије за општине Прешево, Бујановац и Медвеђа у сарадњи са државним и локалним институцијама. Након сагледавања и анализе затеченог стања у области познавања и употребе српског језика, дефинисане су бројне препоруке чије реализације, које су у току, треба да доведу до значајног побољшања у овој области.

Кључне ријечи: српски као нематерњи језик, нациналне мањине, унапређење наставе, препоруке, глотодидактика.

Изградња заједничког суживота припадника различитих националних или етничких заједница уз развијање дијалога и поштовање етничке, културолошке, вјерске и језичке различитости представља оквир за развој савременог друштва и дио је бројних докумената Уједињених нација, Савјета Европе и Организације за европску сарадњу и безбиједност, чији потписник је и Република Србија. У овим оквирима потребно је посматрати и процес интеграције националних 
мањина унутар језички и етнички разноликих друштава. Употреба заједничког, државног језика значајан је предуслов за развој свих димензија друштвеног живота и успјешну интеграцију у шири друштвени оквир. Наглашавајући значај борбе против дискриминације у области образовања, у Конвенцији UNESCO истиче се да је једно од основних права националних мањина образовање на матерњем језику, али под условом „да се ово право не врши на начин који онемогућава припаднике ових мањина да разумеју културу и језик читаве заједнице и да учествују у њеним активностима“" (чл.5, ст.1), што за последицу може да има самоизолацију етничке заједнице, посебно у језички хомогеној средини (Бошковић, 2014).

Препознавши проблем језичке самоизолације усљед недовољног познавања српског језика на југу Србије у општинама Прешево и Бујановац, у којима је већинско становништво албанске националне припадности и у којој је значај учења српског као државног језика занемариван дуги низ година, Координационо тело Владе Републике Србије, покренуло је читав низ активности како би се дефинисало постојеће стање у вези са српским као нематерњим језиком и пронашло одговарајуће системско рјешење.

Први корак је био покретање израде Студије о могућностима унапређења наставе и учења српског као нематерњег језика у општинама Прешево, Бујановац и Медвеђа, у којој би се јасно и документовано представила језичка, али и шира, социокултуролошка слика стања у ове три општине, са стручним анализама и препорукама за побољшање и дугорочно рјешење проблема на ужем језичком, медодичко-педагошком, и ширем, социокултуролошком плану.

Служба координационог тела је организацију Студије започела 2013. године, а њена реализација је подржана од стране Амбасаде Велике Британије и Канцеларије високог комесара за националне мањине. Истраживања за потребе студије подржана су и од Министарства просвете, науке и технолошког развоја РС. За анализу језичких садржаја и обраду статистичких података Студије ангажовани су стручњаци са факултета у Београду и Новом Саду. 


\section{Оквир, циљеви и методологија истражвања}

Како би се обезбиједила што већа транспарентност овог истраживања, али и прикупили подаци шире друштвене заједнице, која својим дјеловањем утиче на учење и употребу српског језика, консултовани су релевантни друштвени чиниоци: народни посланик у Скупштини РС из албанске заједнице, председници општина Прешево, Бујановац и Медвеђа, просвјетни савјетник надлежан за Пчињски и Јабланички округ, директори 16 основних школа, наставници који у тим школама предају српски као нематерњи језик, ђаци, њихови родитељи, представници локалних медија и цивилног друштва.

Оквир истраживања су представљали важећи закони и прописи којима су у Републици Србији регулисана права националних мањина, прије свега у области образовања на матерњем језику. Одређена је методологија педагошког истраживања:

- тестирања ученика 4. и 8. разреда у 16 школа у којима се настава реализује на албанском језику; одлучено је да се тестирају ученици на крају првог и другог циклуса основног образовања како би се могли установити језички нивои у познавању језика;

- посматрање наставе српског као нематерњег језика како би се донијели валидни закључци о примјени лингвистичко-методичких и педагошких приступа од стране предавача, однос ученика према предмету, као и укупна атмосфера на часовима;

- анализа важећег наставног плана и програма за предмет српски као нематерњи језик;

- детаљна језичка(граматичка и лексичко-културолошка) и методичка анализа постојећих уџбеника и приручника који ce, као једина глотодидактичка средства користе у настави српског као нематерњег језика;

- анализа мишљења наставника и ученика у вези са усклађеношћу и примјеном програма, одговарајућим наставним средствима, броју часова, циљевима и потребама ученика итд.

Циљеви које су истраживачи поставили дефинисани су у двије тачке: 
1. установити постојеће стање у настави српског као нематерњег језика, што укључује посматрање наставе, тестирање ученика, анализу програма и дидактичких средстава, анкетирање свих релевантних чинилаца у вези са наставом српског језика, и

2. дефинисати закључке и дати препоруке за побољшање постигнућа ученика и укупног стања у реализацији наставе српског као нематерњег језика.

\section{Резултати истраживања}

Према мишљењу свих наведених саговорника и на основу анализе добијених података намеће се неколико кључних констатација:

1. потребно је побољшати квалитет наставних средстава, реализовати обуке наставника који предају нематерњи језик и омогућити наставницима стручно усавршавање из области техника учења;

2. ученици мисле да им знање српског језика може бити корисно у будућности, како због формалних разлога (школовање, запошљавање, обављање дневних послова), тако и за свакодневну комуникацију у школи и ван ње;

3. сви интервјуисани родитељи сматрају да њихова дјеца треба да науче службени језик државе ради комуникације, дружења и споразумијевања са својим вршњацима различите националне припадности;

4. настава српског као нематерњег језика и знање ученика у основним школама у наведене три општине нису на задовољавајућем нивоу - ученици не могу да остваре комуникацију на српском језику!

\section{Запажања из учионице}

На основу посматрања реализације наставног процеса у учионици уочени су и дефинисани бројни недостаци с обзиром на савремени методички приступ:

- наставнци се придржавају садржаја и динамике наставног плана и програма, без обзира на постигнућа ученика; тем- 
по излагања и начин утврђивања градива није компатибилан са постигнутим језичким компетенцијама ученика и не даје скоро никакве резултате;

- настава се одвија једносмијерно, наставник има доминантну улогу, а жељене реакције ученика скоро да нема, осим у појединачним случајевима када су у питању ученици који говоре српски језик;

- с обзиром на немогућност успоствањање било ког вида комуникације, на часовима се углавном користи преводна метода, како у објашњавању граматичке материје, тако и у објашњавању непознати ријечи;

- уочене су једине „продуктивне“ активности ученика - преписивање на ћирилицу без разумијевања текста и читање без разумијевања.

\section{Тестирање ученика}

Како би се добило чињенично стање у вези са познавањем српског језика, тестирани су сви ученици четвртог и осмог разреда у свих шеснаест основних школа у којима се настава одвија на албанском језику. Тестом се провјеравало функционално знање језика кроз три језичке вјештине: слушање (разумијевање слушаног текста), читиање (разумијевање текста који се чита) и йисање (лексичка и граматичка компетенција кроз усмјеравану и самосталну продукцију). Језичка вјештина іовор провјеравала се само код ученика који су постигли задовољавајуће резултате на тесту. Тестом су заступљени минимални језички садржаји у оквиру постојећег плана и програма, тј. симулирана је функционална употреба језика. Тестом се нису провјеравала знања из књижевности и културе. Инструкције о попуњавању теста дате су двојезично, на српском и албанском језику, а са циљем што потпунијег разумијевања захтјева, ученицима је и усмено, на албанском језику, речено како треба да попуњавају свако од питања. И поред тога, за сваки задатак дат је модел рјешавања задатка.

Тест је штампан латиницом, с обзиром на то да се, по важећем програму, ћирилично писмо учи тек у другом полугодишту четвртог разреда, али се провјера познавања овог писма вршила посебним задатком у тесту. 
Ученици и наставници су упознати са тим да резултати постигнути на тесту ни на који начин неће утицати на оцјену из тог предмета, нити ће се уносити у дневник.

Обим теста је прилагођен очекиваном времену рјешавања од 45 минута, тј. једном школском часу.

\section{Резултати тестирања}

На основу резултата тестирања дефинисани су одређени закључци:

- ученицима је непознат овакав облик теста као средства за провјеру знања; без обзира на детаљна упутства за његово рјешавање, ученици углавном нису знали шта се од њих тражи, те су у највећем броју случајева остављали потпуно празне просторе за одговор или су преписивали модел рјешења задатка;

- осим писања ћирилице (преписивања појединачних ријечи у четвртом и краћих реченица у осмом разреду), ученици, у највећем броју, нису показали потребан минимум језичких компетенција ни у једној језичкој вјештини;

- од укупно тестирана 433 ученика, 33 ученика (11 из 4. и 22 из 8. разреда) остварила су знатно бољи резултат, те је код њих урађена и процјена вербалне компетенције; на основу обављеног интервјуа са тим ученицима дошло се до сазнања да њихово знање српског језика није стечено у наставном процесу ${ }^{1}$.

\begin{tabular}{|l|c|c|}
\hline \multicolumn{3}{|c|}{ Општине Бујановац и Прешево } \\
\hline \multicolumn{1}{|c|}{ Језичке компетенције } & IV разред & VIII разред \\
\hline Граматичка писменост & $5,67 \%$ & $9,56 \%$ \\
\hline Лексика & $6,52 \%$ & $2,04 \%$ \\
\hline Самостална писмена продукција & $4,34 \%$ & $10,76 \%$ \\
\hline Разумијевање слушаног текста & 2,85 & $6,27 \%$ \\
\hline Разумијевање писаног текста & 2,78 & $2,94 \%$ \\
\hline
\end{tabular}

Остварене просјечне вриједности ученика 4. и 8. разреда

1 Детаљни подаци о добијеним вриједностима на тестирању ученика, по школама и појединачним језичким вјештинама видјети у: Крајишник и Стрижак, 2014. 


\section{Анализа уџбеника}

Анализом уџбеника и уџбеничких комплета (Студија 2014), њихових структурно-садржајних концепата, дистрибуције и дозирања језичких садржаја, може се закључити сљедеће:

- уџбеници за српски као нематерњи језик конципирани су по угледу на српски као матерњи језик; осим уџбеника за први и дјелимично дуги разред основне школе, у којима преовлађују илустрације, али и тада са обиљем лексичког материјала који их прати; сви други уџбеници немају дозиран и селективан приступ језику, како по обиму грађе, тако и по њеној дистрибуцији по наставним јединицама;

- лексички фонд по лекцијама, као и укупни (559 само за 1. разред), преобиман је и тешко савладив;

- врло слаба или никакав диференцијација уџбеничке грађе према нивоима знања ученика; иако у читанкама постоје два нивоа текстова селектована по тежини, ниједан од њих није у складу са компетенцијама ученика који српски језик уче у језички хомогеној средини са којим се сусрећу први пут са поласком у школу и током школовања једино у учионици;

- књижевни текстови су преобимни, несавладиви и деморалишући за ученике који немају предзнање из српског језика, а наставнике доводе у незавидну ситуацију у којој не знају како да ученицима представе захтјевне књижевноумјетничке садржаје;

- културолошки садржаји нису прилагођени свим националним мањинама, тако да се у уџбницима налазе подаци о хришћанским вјерским празницим (Божић, Ускрс, слава), али не и муслиманским, топоними се односе само на сјеверну и централну Србију, али не и на источну и јужну, избор личних имена не узима у обзир припаднике свих националних мањина. 


\section{Анализа наставног плана и програма}

Наставним планом за основно образовање предвиђено је да предмет Српски као нематерњи језик буде заступљен у свим разредима основне школе и обавезан за све ученике који наставу похађају на језику националне мањине ${ }^{2}$. Осим на српском, као званичном језику државе, настава у РС се реализује на албанском, бугарском, мађарском, румунском, русинском, словачком, босанском и хрватском језику. Увидом у актуелни наставни план и програм за српски као нематерњи језик издвајамо сљедеће закључке:

- јединствен је за све националне мањине, без обзира на матерњи језик и национално окружење; иако се поштује принцип „вертикалне корелације“, шиио йодразумева gа се одређени број сиирукииура из разреgа у разред шири, оне се развијају и комбинују, ияе се оg јеgностиавнијеі ка сложенијем, а нова ірађа наслањ а се на ирреиххону (Звекић-Душановић, 2014: 51), не постоји хоризонтална корелација која би уважила различите степене (пред)знања и језичко окружење у коме се ученик налази;

- план и програм прописује одговарајући темпо усвајања градива, што је, за ученике у хомогеним језичким срединана чији матерњи језик није сродан српском - немогуће постићи;

- недовољно је експлицитан у очекивању језичких постигнућа, тако да се од свих ученика, без обзира на језичко поријекло и предзнање очекују иста постигнућа;

- планом и програмом је предвиђена обрада неких граматичких јединица прије него што су обрађене на албанском језику;

- инсистира се на граматичким и књижевним садржајима, а врло мало на функционалној употреби језика.

\section{Препоруке за унапређење наставе српског као страног језика}

На основу свеобухватне анализе наставе српског као нематерњег 
језика у основним школама у општинама Прешево и Бујановац, стручни тим који је радио на реализацији Студије предложио је препоруке за унапређење наставе српског као нематерњег језика. Препоруке су засноване на лингвистичко-методичким, педагошким и социо-културолошким аспектима, а с обзиром на временску могућност реализације подијељене су на краткорочне, средњорочне и дугорочне.

\section{Краткорочне препоруке (2014/2015):}

- обезбиједити нова издања уџбеника за више разреде у којима су још увијек у употреби стара, неактуелизована издања;

- обезбиједити додатни дидактички материјал (постери, мапе, различите врсте приручника итд.) који значајно олакшава рад наставницима, али и мотивише активност ученика;

- организовати обуке за наставнике - на основу анализе стручне спреме 41 наставника установљено је да само њих шест испуњава услове према Правилнику о степену и врсти образовања наставника и стручних сарадника у основној школи; овакво стање намеће потребу за организовањем семинара и радионица којима ће се наставници едуковати за примјену савремених методичких приступа настави језика, коришћење постојећих наставних материјала и начине за самостално припремање материјала у зависности од потреба ученика; обуке за наставнике треба да садрже и активности са циљем побољшања владања стандардним српским језиком и код самих наставника;

- организовати сусрете са наставницима из других националних средина како би се наставницима омогућило сагледавање проблема из друге перспективе (наставници који предају ученицима мађарске националне припадности имају скоро истовијетан проблем у реализацији наставе српског као нематерњег језика), те њихово заједничко рјешавање;

- ангажовати асистенте за помоћ наставницима, прије свега оним наставницима којима српски није матерњи језик; асистенти треба да буду квалификовани за давање такве врсте помоћи (да им је матерњи језик српски, да имају диплому професора српског језика и да су обучени у глотодидактичком 
смислу); асистенти би помагали у реализацији наставе и уносили динамику и нове идеје у оквиру активности на часу;

- увести квартална тестирања ученика како би се пратила примјена нових приступа настави од стране наставника, као и њихов утицај на постигнућа ученика;

- иницирати организовање такмичења из српског као нематерњег језика са циљем повезивања ученика свих националних мањина у РС који уче српски језик и стварање атмосфере позитивне конкуренције;

- $\quad$ формирање радне групе за праћење имплементације препорука.

Све наведене кракорочне препоруке реализоване су у предвиђеном периоду, што је резултирало значајним побољшањем у настави српског као нематерњег језика, а што је предмет једног другог истраживања.

\section{Средњорочне препоруке (2015-2017):}

- $\quad$ написати приручнике за наставнике за други циклус обавезног образовања (од 5. до 8. разреда) који ће омогућити наставницима бољу имплементацију уџбеничког садржаја у наставни процес;

- написати двојезични рјечник којим ће се и наставницима и ученицима омогућити лакши рад на часу и код куће;

- обезбиједити континуирану обуку наставника са циљем сталног усавршавања наставника у препознавању и примјени нових метода у процесу наставе језика;

- успоставити везе међу школама из различитих националних заједница (посјете ученика и наставника); коначни циљ ових сусрета је комуникација на српском језику ученика различитих националних мањина који се школују у Србији, али и сагледавање заједничких проблема који прате ову врсту наставе;

- дефинисати стандарде и исходе за српски као нематерњи језик којима ће се знатно олакшати рад наставницима и омогућити „увођење“ функционалног језика у наставни процес; стандарди и исходи ће дефинисати циљеве у учењу језика, али и омогућити валидну евалуацију стеченог знања; 
- увести обавезно национално тестирање;

- ускладити наставни програм за предмете Албански језик и Српски као нематерњи језик.

\section{Дугорочне препоруке:}

- обезбиједити услове за школовање новог наставног кадра у складу са стандардима савремене методике наставе језика;

- обезбиједити услове за учење албанског језика за припаднике већинског становништва; наиме, спремност већинске заједнице да учи језик националне мањине умногоме утиче на рзвој свијести о толеранцији и побољшању квалитета заједничког живота;

- актуелизовати наставни материјал према потребама наставника и ученика;

- анализирати потребу за измјенама и допунама наставног програма у складу са новим стандардима и исходима.

Српски као нематерњи језик је врло осјетљиво питање већ дужи низ година у нашој вишенационалној и вишејезичкој средини, које увелико излази из оквира лингвистичко-методичког и педагошког интересовања. Управо због тога, овом предмету у нашем школском систему је потребно прићи на комплексан, свеобухватан и сензибилан начин како би се дошло до ваљаног системског рјешења које ће дати жељене резултате - комуникацију на српском језику међу свим држављанима Републике Србије, односно познавање језика на нивоу који омогућава припадницима свих националних мањина несметано обављање дневних активности, школовање и запошљавање.

предмет Српски као нематерњи језик за крај првог и другог циклуса обавезног образовања, општег средњег образовања и основног образовања одраслих објављен је у “Службеном гласнику РС”, бр. 55/2017 од 2.6.2017. године, а ступио је на снагу 10.6.2017. 


\section{Референце:}

Бошковић (2014): Бошковић, Н. Концептуални оквир - значај језика

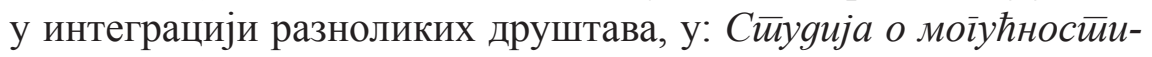
ма унайређена насйаве и учењ а срйскої као немайерњеі̄ језика у ойшииинама Прешево, Бујановач и Меgвеђа, Београд: Служба координационог тела Владе Републике Србије за општине Прешево, Бујановац и Медвеђа, 21-28.

Звекић-Душановић (2014): Звекић-Душановић, Д. Анализа наставног плана и програма за српски као нематерњи језик за основну школу, у: Сйудија о могућносииима унаирређења настиаве и учења срйской као немайерњеі̄ језика у ойшйинама Прешево, Бујановач u Меgвеђа, Београд: Служба координационог тела Владе Републике Србије за општине Прешево, Бујановац и Медвеђа, 49-66.

Крајишник, Стрижак (2014): Крајишник, В. и Н. Стрижак. Анализа резултата тестирања, у: Сйуgија о моіућносииима унайређења настиаве и учењ а срйскої као немайерњеї језика у оитииинама Прешево, Бујановац и Меgвеђа, Београд: Служба координационог тела Владе Републике Србије за општине Прешево, Бујановац и Медвеђа, 123-150.

Сйудија о моїућносииима унайређењ а настиаве и учењ а срйскоі̄ као немайерњеі̄ језика у ойшииннама Прешево, Бујановаи и Меgвеђа, Београд: Служба координационог тела Владе Републике Србије за општине Прешево, Бујановац и Медвеђа,196. 


\title{
Vesna Krajišnik
}

\section{THE STATE OF TEACHING SERBIAN AS A NON-MOTHER TONGUE IN HOMOGENEUS LINGUISTIC CONTEXTS AND RECOMMENDATIONS FOR ITS FURHTER DEVELOPMENT}

\begin{abstract}
Summary
This paper outlines problems in teaching Serbian as a non-mother tongue in the municipalities of Preševo and Bujanovac, which were identified after an extensive analysis carried out by Office of the Coordination Body of the Government of the Republic of Serbia for the Municipalities of Presevo, Bujanovac and Medvedja and. Apart from presenting the current situation, the actions taken in order to solve the encountered problems are analyzed and results from the fieldwork presented: recommendations for improving the teachers' competences, changes in teaching approaches and teaching methods, understanding curriculum, introducing assistants in the classrooms. After only one school year the above cited activities have made significant improvements in teaching Serbian as a non-mother tongue in Preševo and Bujanovac.
\end{abstract}

Key words: Serbian as a non-mother tongue, Preševo and Bujanovac, teacher training, analysis of fieldwork. 